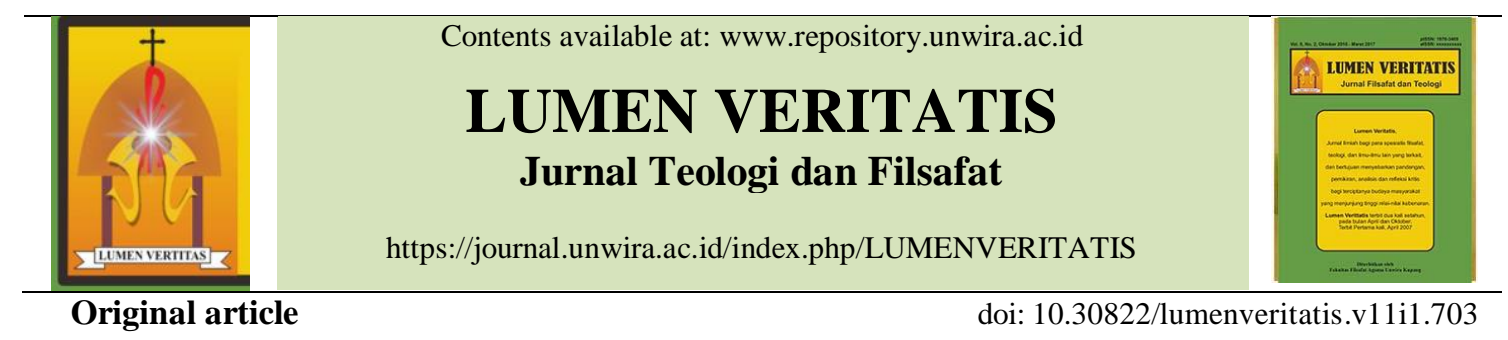

\title{
RELEVANSI TRINITAS BAGI HIDUP MANUSIA MENURUT KARL RAHNER
}

\author{
Herman Punda Panda \\ Program Studi Ilmu Filsafat, Fakultas Filsafat, Universitas Katolik Widya Mandira \\ Email: hermanpanda02@gmail.com
}

\begin{abstract}
Karl Rahner made a major contribution to the trinitarian theology in this post-modern era. He has attempted to reconcile the classical doctrine of the Trinity with contemporary thought. Rahner spoke about the topic of the oneness and triadity of God. Regarding the oneness of God, Rahner did not speak about the one ousia / divine essence, but rather the unity or perichoresis of the three divine persons. What is called God here, is not the essence of divinity but the Father who is the source of the Son and the Holy Spirit. Furthermore, Rahner emphasizes the identification and relationship between the immanent Trinity and the economic Trinity which according to him is the important point in the theology of the Trinity. Consequently, the only starting point for developing a theology of the Trinity is the history of our experience with God, in which God reveals Himself in two ways, namely through the Word and the Spirit. This article presents Karl Rahner's thoughts on the Trinity and its relevance to human life. First of all, the author describes about the place of Trinitarian theology in the general framework of Rahner's anthropological theology. Next, it discussed his thoughts on the Trinity itself and at the end, the relevance of the Trinity to human life. This relevance becomes evident in Rahner's thought about the communication of God to man in the form of His Word and Spirit.
\end{abstract}

Keywords: Trinitas, Manusia, Komunikasi, Sejarah, Kebernaran, Roh, Cinta

\section{Pendahuluan}

Karl Rahner (1904-1984) memiliki kontribusi yang amat besar dalam teologi trinitaris di zaman pasca-modern ini. Di kalangan para teolog, nama Karl Rahner hampir selalu dikaitkan dengan pemikirannya tentang Trinitas. Karena itu seorang penulis menganalogikan Rahner dengan Einstein: sebagaimana teori Fisika Quantum sepertinya tidak dapat dipisahkan dari nama Einstein, demikian juga Trinitas dari nama Karl Rahner. ${ }^{1}$

${ }^{1}$ Milton, Michael Kobus, The Doctrine of the Trinity According to Karl Rahner, dalam https://rdtwot.files.wordpress.com/2007/10/kobu
Walaupun demikian, sebagaimana diamati oleh Peter C. Phan, sebenarnya tidak banyak karya Rahner yang berbicara khusus tentang Trinitas. Dalam karya besarnya Grundkurs des Glauben (Terjemahan Inggris: Foundations of Christian Faith), hanya empat halaman yang berbicara tentang Trinitas, di bawah judul "Towards an Understanding of the Doctrine of the Trinity." Selain itu, ada beberapa bagian kecil dalam karya besarnya yang lain Theological Investigation, dan dua entries dalam

s the-doctrine-of-the-trinity-according-to-karlrahner.pdf 
ensiklopedi Sacramentum Mundi (1970). ${ }^{2}$ Dari dua artikel dalam Sacramentum Mundi tersebut, belakangan dikembangkannya dan diterbitkan dalam Bahasa Inggris berupa buku kecil berjudul The Trinity, yang merupakan satu-satunya ulasan terpanjang Rahner tentang Trinitas.

Apa kekhasan teologi Rahner, secara khusus ulasannya tentang Trinitas? Secara umum ulasan teologi Rahner mendapat apresiasi dari banyak teolog lain. J.B. Metz mengamati bahwa karya Rahner berpengaruh penting di zaman pasca-modern ini karena menyatukan kembali apa yang selama periode panjang telah dipisahkan yaitu teologi dan sejarah, doktrin dan hidup, mistik dan keseharian. ${ }^{3} \quad$ Sedangkan Teolog Pembebasan Leonardo Boff amat menghargai ungkapan yang dipilih Rahner tentang Bapa, Putera dan Roh Kudus sebagai tiga cara berada yang berbeda-beda dari Trinitas (a distinct manner of subsisting). Akan tetapi Boff tetap mempertahankan penggunaan kata persona yang merupakan padanan dari istila Yunani hypostasis, karena menurutnya, kata persona (pribadi) amat penting bagi suatu teologi pembebasan yang efektif. ${ }^{4}$ Demikian juga konsep Rahner tentang cara berada yang amat nyata dari Trinitas sebagai jantung dari iman Kristiani, ${ }^{5}$ secara tidak langsung didukung oleh Friedrich Schleiermacher dan juga Paul Tillich yang menempatkan Trinitas secara simbolis sebagai bantuan

\footnotetext{
${ }^{2}$ Peter C. Phan, "Mystery of grace and salvation: Karl Rahner's theology of the Trinity" dalam Peter C. Phan (ed.), The Cabridge Companion to The Trinity (New York: Cambridge University Press, 2011), hlm. 192.

3 J. B. Metz, A Passion for God (New York: Paulis, 1998), hlm. 103.
}

bagi akal budi manusia untuk memahami Allah secara lebih baik.

Pemikiran teologis Rahner tentu tidak lahir begitu saja melainkan menempu proses pembentukan yang panjang selama masa pendidikannya sampai karyanya sebagai professor. Ada beberapa pribadi yang berpengaruh penting bagi hidup dan pemikiran teologis Rahner. Pertama-tama, sebagai seorang Jesuit, dia menyadari pengaruh St. Ignatius dari Loyola yang memberi dimensi mistik yang kuat bagi pemikiran teologisnya. Rahner menulis, "Pemikiran teologis saya lahir dari latihan Spiritual Ignatian, dan dengan demikian dibentuk dalam terang refleksi atas kekuatan karya Roh".6 Selanjutnya, dalam pemikiran Rahner tentang Allah yang terlibat dalam dunia ciptaannya, amat nyata pengaruh Ignatius yang memiliki semboyan "menemukan Allah dalam segalanya".

Thomas Aquinas juga memiliki pengaruh penting bagi Rahner, terutama melalui Joseph Marechal, seorang Jesuit dari Belgia, juga mentor Rahner, yang memiliki cara menafsirkan Thomas Aquinas secara berbeda dari para Thomist lainnya. Rahner menyadari bahwa Marechal amat membantunya dalam masa awal pengembangan wawasan filosofisnya, terutama perjumpaan antara filsafat skolastik yang tradisional dan filsafat modern. Thomisme transendental Marechal turut membantu memperluas horizon Thomistik Rahner yang melampaui buku

\footnotetext{
${ }^{4}$ Ted Peters, God as Trinity: Relationality and Temporality in Divine Life (Louisville, Kentucky: John Knox Press, 1993), hlm. 35.

${ }^{5}$ Mary Ann Fatula, The Triune God of Christian Faith (Minnesota: Liturgical Press, 1990), hlm. 77

6 Karl Rahner, Theological Investigationsvol. XVI, (New York: Crossroad, 1983), p. x
} 
pegangan tradisional filsafat skolastik. ${ }^{7}$ Dari Marechal pula dia mendapat persiapan yang baik untuk kemudian belajar di bawah Martin Heidegger.

Pribadi lain yang juga berpengaruh bagi Rahner adalah Martin Heidegger. Dua tahun Rahner belajar filsafat di bawah Heidegger yang dia akui membantunya dalam pergolakan untuk menyatukan filsafat modern ke dalam teologi kristiani zaman ini. $^{8}$ Pengaruh Heidegger amat nyata dalam gagasan Rahner tentang realitas existensial manusia yang "terbenam dalam dunia". Dari sana pula dia mengembangkan persepsinya tentang Trinitas ekonomis.

Artikel ini mengemukakan pemikiran Karl Rahner tentang Trinitas dan relevansinya bagi hidup manusia. Pertama-tama dikemukakan tentang tempat teologi Trinitaris dalam kerangka umum teologi anthropologinya. Selanjutnya, diuraikan pemikiran Rahner tentang Trinitas itu sendiri. Pada akhirnya dibahas tentang relevansi Trinitas bagi hidup manusia. Relevansi tersebut menjadi nyata dalam pemikiran Rahner tentang komunikasi diri Allah kepada manusia dalam bentuk Sabda dan RohNya.

\section{Trinitas dalam kerangka umum teologi Rahner}

\footnotetext{
${ }^{7}$ Paul Imhof dan Hubert Biallowons (eds.), Karl Rahner in Dialogue: Conversations and Interviews 1965-1982, Terjemahan Inggris: Harvey D. Egan (New York: Crossroad 1986), p. 255.

8 Meinold Krauss, Karl Rahner: I Remember (Suatu wawancara Autobiografis), (New York: Crossroad 1985), hlm 45.

9 Spirit in the World, judul asli Geist im Welt merupakan judul dari dissertasi Rahner di Universitas Freiburg sekaligus salah satu karyanya yang amat berpengaruh. Karya ini
}

Rahner memulai teologinya dari anthropologi. Menurutnya, pribadi manusia adalah roh dalam dunia (spirit in the world). ${ }^{9}$ Sejauh manusia adalah roh, sudah selayaknya dia melampaui dirinya dalam tindakan bebas ke arah yang tak terbatas dengan mengenal Dia sebagai cakrawala cinta dan kebenaran. Yang tak terbatas itu tidak lain dari misteri Ilahi atau Allah sendiri. ${ }^{10}$ Tindakan melampaui diri ini merupakan pula pencapaian antisipatif manusia pada Ada nan Mutlak walaupun manusia tidak dapat menggapainya sebagai obyek. Hal ini lalu menyingkapkan hakikat diri manusia sebagai potentia obedientialis (kemampuan untuk mendengar) pernyataan diri Allah. Inilah disposisi eksistensial setiap manusia yaitu menjadi penerima Sabda atau mitra komunikasi diri Allah. Tetapi selama manusia masih di dunia ini, dia dapat menjalankan tindakan melampaui diri ini hanya dalam sejarah, dalam ruang dan waktu. Karena itulah Allah sendiri dengan kebebasanNya memilih untuk berbicara kepada manusia. Dalam hal ini Allah pun melakukanNya hanya dalam dan melalui peristiwa-peristiwa sejarah. Ketika melakukan demikian, Allah menyatakan diriNya bukan sebagai Allah yang jauh melainkan Sang Imanuel, Allah yang beserta kita, yaitu Allah yang masuk dalam sejarah manusia. Dan hanya dari

mendapat pengaruh kuat dari Thomisme transendental Marechal dan Existensialisme Heidegger. Diolah lebih lanjut dan terbitkan tahun 1939, edisi Bahasa Inggris tahun 1968 oleh Penerbit Sheed and Ward (London) dan Herder and Herder (New York).

${ }^{10}$ Karl Rahner, Foundations of Christian Faith: An Introduction to theIdea of Christianity, trans. William V. Dych (New York: Seabury, 1978), hlm.

65. 
sudut pandang iman, manusia memahami bahwa Allah masuk dalam sejarah dan menganugerahkan diriNya kepada kita. Iman kristiani memahami pemberian diri Allah ini sebagai Sabda yang menjelma dan Roh yang menganugerahkan rahmat.

Walaupun tidak sama persis dengan Agustinus atau Thomas Aquinas, Rahner juga menggunakan "gambaran psikologis" yaitu kegiatan mengenal dan mencintai dalam diri manusia untuk memahami Trinitas. Bagi Rahner, bukan mengenal dan mencintai itu sendiri yang merupakan analogi tentang Trinitas melainkan mengenal dan mencintai yang lain di luar diri. Pengenalan akan yang lain di luar diri, pada akhirnya tertuju kepada Allah yang hadir dalam dunia dan sejarah. Dalam pemahaman seperti ini, kita dapat katakan bahwa Teologi Trinitas Rahner adalah teologi "dari bawah", yaitu bertitik tolak dari pengalaman konkret manusia akan pemberian diri Allah melalui tiga cara yang berkaitan erat yaitu sebagai Bapak, Putera dan Roh Kudus.

Menurut Rahner, titik tolak teologi Trinitas adalah peristiwa pemberian diri Allah dalam sejarah yaitu penjelmaan Sabda menjadi manusia dan penganugerahan Roh Kudus. Dengan pemberian diri seperti itu kita mengenal Allah sebagai Trinitas (Trinitas Ekonomis) dan dengan itu pula teologi tentang Trinitas dibangun. Teologi seperti ini menuntun kita pada pengenalan akan hakikat Allah sebagai Trinitas dalam keabadian (Trinitas Imanen) terlepas dari hubungannya dengan dunia. Hal ini didasarkan pada keyakinan bahwa Allah tak pernah berubah. Kalau Dia menyatakan diriNya dalam sejarah sebagai Bapa, Putera dan Roh Kudus, mestinya sebelum segala abad Dia adalah Bapa, Putera dan Roh Kudus dalam keabadian.

Tidak seperti kebanyakan teolog yang menekankan keberadaan seluruh umat manusia dalam dosa dan dengan demikian memerlukan penebusan Kristus, Rahner memandang kenyataan umat manusia secara lebih optimistik. Rahner berpandangan bahwa sejarah umat manusia secara terus menerus diresapi oleh pemberian diri Allah yang diwujudkan dalam penjelmaan Sabda dan penganugerahan Roh Kudus. Walaupun tidak disangkal kenyataan berdosa dalam umat manusia, tetapi sesungguhnya dunia ini juga tetap dipenuhi rahmat. Di dalam dunia seperti itu, manusia memiliki "kemampuan mendengar" (potentia obedientialis) sehingga setiap manusia apa pun latar belakangnya (Kristen, nonKristen) menjadi suatu keberadaan supernatural (supernatural existential). Ini berarti bahwa manusia memiliki dimensi rahmat dalam dirinya yang mampu mempengaruhi kesadarannya.

\section{Allah Yang Esa dan Tritunggal}

Dalam menelusuri ajaran tentang Trinitas dari Agustinus dan Thomas Aquinas, Rahner menyaksikan suatu struktur tentang Allah yang satu dan Trinitas.Begitu pula dalam buku pegangan teologi neo-skolastik, pembicaraan tentang Allah biasanya dibagi atas dua bagian: tentang Allah yang satu (De Deo Uno) dan Allah yang Trinitas (De Deo Trino). Rahner mengamati bahwa kedua bagian itu walaupun sama-sama bersumber dari 
wahyu ilahi tetapi tampaknya sedikit saja hubungan antara mereka. ${ }^{11}$

Selain itu, Rahner mengamati pula bahwa dalam era yang disebut zaman pencerahan (abad ke-18) teologi Kristen sedang berusaha menjawabi tantangan Deisme dan Atheisme. ${ }^{12}$ Akibatnya teologi dalam kerjasama dengan filsafat lebih menyibukkan diri untuk memberikan argumen-argumen yang kuat tentang keberadaan Tuhan. Dengan itu teologi kurang memberi penekanan pada Wahyu Kristiani yang berbicara tentang "siapa Tuhan itu" dan "bagaimana karakter dan tindakanNya", sebaliknya lebih pada "apa Tuhan itu" dan "apa atribut-atributNya". ${ }^{13}$ Dalam pendekatan seperti itu, tidak terelakkan lagi bahwa Allah yang satu mendapat penekanan yang lebih dari pada Allah dalam pemahaman Kristiani sebagai Bapak, Putera dan Roh Kudus yang hadir dan bergiat dalam sejarah.

Akibat lanjut dari pemahaman seperti di atas, ciptaan hanya sekadar dilihat sebagai kegiatan ke luar (ad extra) dari Trinitas seluruhnya dalam arti Trinitas dilihat sebagai sekadar penyebab keberadaan segala ciptaan. Dengan demikian, ciptaan tidak dilihat juga sebagai karya ciptaan yang berbeda dari setiap pribadi Trinitas sehingga pribadipribadi Trinitas berperanan pula sebagai model.

Bagi Rahner, ada dua hal penting dalam mengembangkan teologi Trinitas: metode dan isinya. Dari segi metode, pertanyaannya adalah: bagaimana pembicaraan tentang Trinitas harus

11 Karl Rahner, The Trinity, terjemahan Joseph Donceel (New York: Crossroad, 1997), hlm.1517.

12 Deisme adalah kepercayaan pada Tuhan sebagai penyebab pertama keberadaan segala disusun? Rahner tidak mengikuti pembagian pembicaraan tentang Allah menurut teologi skolastik seperti di atas. Dia memahami bahwa keesaan Allah meliputi kesatuan atau lebih tepat perichoresis di antara ketiga pribadi Ilahi. Sedangkan Allah, menurutnya, menunjuk Bapak yang merupakan sumber dari Putera dan Roh Kudus. Dengan pemahaman seperti ini, maka pembagian pembicaraan tentang Allah atas dua bagian (De Deo Uno dan De Deo Trino) menjadi tidak lagi penting.

Dari segi isi, Rahner menekankan hubungan antara Trinitas imanen (Trinitas dalam diriNya sendiri terlepas dari dunia dan sejarah) dan Trinitas ekonomis (Trinitas yang tampak dalam sejarah sebagai Bapak, Putera dan Roh Kudus). Menurut Rahner, hal ini merupakan pokok penting dalam teologi Trinitas.

\section{Rumusan Rahner: Trinitas imane adalah Trinitas ekonomis}

Rahner menegaskan bahwa Trinitas imanen adalah Trinitas ekonomis, dan sebaliknya Trinitas ekonomis adalah Trinitas imanen. ${ }^{14}$ Dalam hal ini bukan dua Trinitas yang sama persis satu dengan yang lain. "Adalah" di sini bermakna "tidak lain dari". Trinitas ekonomis yaitu Trinitas yang kita kenal dalam sejarah melalui pewahyuan diriNya sebagai Bapak, Putera dan Roh Kudus tidak lain dari Trinitas imanen yaitu Trinitas dalam keabadian sebelum dan terpisah dari segala ciptaanNya. Dengan penegasan ini, Rahner bertujuan

sesuatu, dan setelah itu seakan-akan lepas tangan terhadap segala ciptaanNya. Sedangkan atheisme menyangkal adanya Tuhan.

13 Peter C. Phan, op.cit., hlm. 195.

${ }^{14}$ Ibid., hlm. 22. 
untuk memahami Trinitas sebagai pusat dari keselamatan umat manusia. Pertamatama Rahner ingin mengembalikan pemahaman tentang Trinitas dalam misteri keselamatan. Menurutnya, dalam teologi neo-skolastik Trinitas telah dipahami secara metafisis dan psikologis sehingga secara total dipisahkan dari sejarah keselamatan, yaitu pernyataan diri Allah dalam sejarah. Karena itu, Rahner menegaskan bahwa pernyataan diri dan pemberian diri Allah kepada umat manusia dalam sejarah (Trinitas ekonomis) tidak lain dari Trinitas abadi yaitu Bapak, Putera dan Roh Kudus yang saling berrelasi satu sama lain dalam keabadian (Trinitas imanen).

Rumusan Rahner "Trinitas ekonomis adalah Trinitas imanen" memiliki konsekuensi yang luas dan mendalam bagi teologi Kristen. Rumusan ini tidak hanya berbicara tentang hubungan dari pribadi-pribadi dalam Trinitas melainkan pula hubungan antara Trinitas dan umat manusia. Jika tiga pribadi ilahi dari Trinitas imanen menyatakan diriNya dalam Trinitas ekonomis dengan perbedaan spesifik mereka berdasarkan hubungan timbal-balik yang abadi, maka umat manusia yang dirahmati berhubungan dengan setiap pribadi ilahi dengan cara yang berbeda dan spesifik pula. Hal ini sejalan dengan cara masingmasing pribadi ilahi menyatakan dirinya dalam sejarah. Rahner mengungkapkan hal ini, "Masing-masing dari tiga pribadi ilahi mengkomunikasikan dirinya kepada manusia dengan rahmat yang diterima secara cuma-cuma dalam kekhasan dan perbedaan pribadi itu sendiri". ${ }^{15}$

Menurut Rahner, ada tiga cara komunikasi diri Allah yang satu itu kepada umat manusia, yaitu sebagai

\footnotetext{
${ }^{15}$ Ibid., hlm. 34-35.
}

Bapa, Putera dan Roh Kudus. Bapa mengkomunikasikan dirinya kepada kita juga sebagai Bapa. Hal ini didasarkan pada pernyataan diriNya sebagai Bapak pada saat menurunkan Putera. Putera tidak lain adalah pernyataan diri Bapak. Selanjutnya Bapak dan Putera saling menerima dan saling mencintai, serta saling tertarik dan bersatu kembali. Hubungan cinta timbal balik antara Bapak dan Putera itulah Roh Kudus. Allah berhubungan dengan kita manusia juga dalam tiga cara yang berbeda, yang dianugerahkanNya secara bebas dan cuma-cuma. Hal ini bukan sekadar salinan atau analogi dari hubungan cinta yang ada dalam Trinitas tetapi Trinitas itu sendiri benar-benar mengkomunikasikan diriNya kepada kita secara bebas dan cuma-cuma dalam tiga cara. ${ }^{16}$

Rahner menyebutkan dua jenis hubungan sebab akibat untuk menjelaskan bagaimana komunikasi diri Trinitas imanen ke dalam Trinitas ekonomis ini menjadikan yang terakhir identik dengan yang pertama. Selain itu juga hubungan tersebut memungkinkan pula manusia yang menerima komunikasi diri ilahi ini untuk memiliki hubungan khusus yang berbeda dengan masingmasing pribadi ilahi.

Komunikasi diri ilahi initerjadi tidak hanya melalui kausalitas efisien melainkan juga kausalitas formal atau lebih tepatnya quasi formal. Melalui kausalitas efisien, komunikasi diri ilahi menciptakan sesuatu yang baru di dalam diri kita yaitu rahmat pengudusan. Sedangkan dengan cara kausalitas formal, atau "quasi-formal", tiga pribadi ilahi memberikan diriNya bagi kita dalam tiga cara berada yang benar-benar berbeda (yaitu, pribadi-pribadi) dalam

${ }^{16} \mathrm{Ibid}$. 
Trinitas imanen. Bapa, disebut demikian tetapi tetap menjadi Misteri yang tak pernah dipahami. Putera adalah Sabda Kebenaran yang diucapkan dari Misteri ini. Sedangkan Roh adalah Cinta dari Misteri ini.

Akibat lain dari rumusan Rahner ini berkaitan dengan metodologi teologis. Jika Trinitas ekonomis adalah Trinitasimanen, maka satu-satunya titik tolak untuk mengembangkan sebuah teologi tentang Trinitas imanen bukanlah suatu analogi yang spekulatif, psikologis atau metafisik, tetapi sejarah pengalaman kita dengan Allah sebagaimana dinyatakan dalam dua cara yaitu melalui Firman dan Roh. Rahner menegaskan: "Kita benar-benar dapat memahami isi dari doktrin Trinitas hanya dengan kembali kepada sejarah keselamatan dan sejarah rahmat, kepada pengalaman kita tentang Yesus dan Roh Allah, yang bergiat di dalam kita, karena di dalamnya kita benar-benar sudah memiliki Trinitas itu sendiri sebagaimana adanya". ${ }^{17}$

\section{Komunikasi diri Allah Bapa dalam du acara: Sabda dan RohNya}

Dalam topik ini, pertama-tama Rahner berbicara tentang komunikasi diri Allah Bapa dalam dua cara yang berbeda yaitu melalui Sabda dan Roh dalam sejarah. Mengikuti tradisi alkitabiah dan para Bapak Gereja Yunani, Rahner memahami bahwa yang dimaksud Allahitu merujuk pada Bapa dan bukan esensi ilahi. Bapak mengkomunikasikan dirinya dalam sejarah sebagai Firman dan Roh sementara dirinya sendiri tetap menjadi sumber keilahian yang tidak berasal dari mana pun, dengan kata lain sebagai Misteri Mutlak.

${ }^{17}$ Ibid., hlm. 40.
Tantangan teologis menurut Rahner adalah bagaimana memahami dua cara komunikasi diri ilahi ini yang pada hakikatnya terkait satu sama lain namun berbeda. Dua cara komunikasi diri ilahi ini dialami dalam sejarah sebagai dua peristiwa yang berbeda. Keduanya seharusnya tidak dipandang sebagai dua fakta yang kebetulan belaka dan tidak terkait satu sama lain, seolah-olah bisa saling dipertukarkan, misalnya Roh dapat berinkarnasi sebagai Firman, dan Firman itu dapat dianugerahkan sebagai Roh. Jika demikian, Trinitas ekonomis tidak akan menyingkapkan kepada kita kebenaran tentang Trinitas imanen. Sebaliknya menurut Rahner, ketika Tuhan dengan bebas keluar dari diriNya dalam komunikasi-diri, tidak hanya melalui penciptaan realitas lain yang bukan diriNya, Puteralah yang seharusnya muncul secara historis dalam daging sebagai manusia. Dan Rohlah yang seharusnya menimbulkan penerimaan atas komunikasi diri ini dari pihak dunia ciptaan dalam rupa iman, harapan, dan cinta. ${ }^{18}$

Perlu dicatat bahwa tindakan komunikasi diri Bapa ini bersifat bebas tetapi tetap diperlukan cara. Dua cara ini tidak sekadar dua "fungsi" Bapa yang dapat dipertukarkan, melainkan bersama dengan Bapa, merupakan Trinitas ekonomis yang identik denganTrinitas imanen.

\section{Empat aspek komunikasi diri Allah Bapa}

Komunikasi diri Allah Bapa dalam dua cara yang berbeda yaitu melalui Firman dan Roh tentu saja mengandaikan bahwa ciptaan sebagai penerima memiliki kemampuan menerima

${ }^{18}$ Ibid., hlm 86. 
komunikasi diri ilahi ini. Penerima yang memiliki kemampuan seperti itu, bagi Rahner, hanya "Roh-dalam-dunia" yaitu pribadi manusia. Berdasarkan hakikat manusia sepertiini, Rahner menguraikan empat aspek yang berpasang-pasangan dari komunikasi diri Allah Bapa: (1) asal mula - masa depan; (2) transendensi sejarah; (3) tawaran - penerimaan; dan (4) cinta - pengetahuan. ${ }^{19}$ Perlu dicatat bahwa keempat pasangan ini mencirikan komunikasi baik diri Allah maupun pribadi manusia sebagai penerima.

Sebagaimana sudah disebutkan bahwa dalam teologinya Rahner memperjumpakan antara teologi dan anthropologi di mana teologi berimplikasi pada antropologi dan sebaliknya. Maka untuk memahami Trinitas ekonomis diperlukan suatu pemahaman atas struktur pribadi manusia sebagai penerima Trinitas ini, dan struktur antropologis inipada gilirannya diterangi oleh dua cara Allah mengkomunikasikan diriNya kepada manusia.

Pasangan aspek pertama dari komunikasi diri ilahi yang sesuai dengan pribadi manusia adalah asal mula dan masa depan. Disebut asal mula, sejauh komunikasi diri Allah menciptakan dan membentuk pribadi manusia sebagai penerimaNya. Sedangkan masa depan, sejauh komunikasi diri ini ketika diterima oleh pribadi manusia cenderung ke arah kepenuhannya untuk direalisasikan di masa depan, meskipun tidak secara deterministik tetapi melalui sejarah kebebasan manusia. Pasangan kedua adalah sejarah dan transendensi. Disebut sejarah sejauh komunikasi diri Allah terjadi dalam dunia dan dibatasi ruang

${ }^{19}$ Ibid., hlm. 88

${ }^{20}$ Ibid., hlm. 88-94. dan waktu. Sedangkan transendensi, sejauh komunikasi diri Allah adalah cakrawala yang menjadi tujuan pribadi manusia ketika menerima komunikasi diri ilahi ini melalui tindakan mengetahui dan mencintai obyek-obyek tertentu. Pasangan ketiga adalah tawaran dan penerimaan. Disebut tawaran sejauh komunikasi diri Allah melibatkan pribadi manusia untuk menerimanya dalam kebebasan. Sedangkan penerimaan sejauh komunikasi diri Allah tidak dapat diterima oleh pribadi manusia kecuali oleh kekuatan yang diberikanNya kepada pribadi manusia untuk melakukannya. Pasangan keempat adalah pengetahuan dan cinta. Disebut pengetahuan sejauh komunikasi diri Allah menghadirkan dirinya kepada manusia sebagai kebenaran mutlak untuk diketahui dan bukan hanya kebenaran khusus. Sedangkan cinta sejauh komunikasi diri Allah menampilkan dirinya kepada manusia sebagai kebaikan mutlak untuk dicintai, dan bukan hanya kebaikankebaikan tertentu. ${ }^{20}$

Rahner selanjutnya berpendapat bahwa keempat pasangan aspek komunikasi diri Allah kepada manusia ini pada hakikatnya terhubung secara erat satu sama lain, meskipun beberapa di antaranya lebih jelas tautan dan hubungannya dari pada yang lain. Tujuan Rahner adalah untuk menunjukkan bahwa ada kesatuan di antara empat pasangan dan bahwa "ada duadan hanya dua cara dasar komunikasi diri Allah, yang berbeda dan saling mengkondisikan sedemikian rupa sehingga karakter spesifik masing-masing dapat dipahami secara konseptual dan dibedakan satu dari yang lainnya". ${ }^{21}$

${ }^{21}$ Ibid., hlm. 94. 
Titik refleksi Rahner di sini ada dua. Di satu sisi, dia ingin menunjukkan kesatuan kelompok pertama dari empat aspek yaitu asal mula, sejarah, tawaran dan pengetahuan, serta kesatuan dari kelompok kedua yaitu masa depan, transendensi, penerimaan dan cinta. Di sisi lain, ia juga ingin menunjukkan bahwa dua kelompok aspek komunikasi diri Allah ini berbeda tetapi tidak terpisah dan saling mengkondisikan. Kelompok pertama dapat diringkas sebagai sejarah atau kebenaran, dan kelompok kedua sebagai roh atau cinta. Rahner menyarankan agar kita menerima bahwa "Komunikasi diri yang ilahiterjadi dalam kesatuan dan perbedaan dalam sejarah (kebenaran) dan dalam roh (Cinta)". ${ }^{22}$

\section{Dari Trinitas ekonomis ke Trinitas imanen}

Kita telah membicarakan pandangan Rahner tentang Trinitas sebagaimana yang kita alami dalam sejarah, yaitu Trinitas ekonomis di mana Allah Bapa mengkomunikasikan diriNya dalam dua cara yaitu kebenaran dan cinta atau Firman dan Roh. Telah diuraikan pula bahwa Trinitas ekonomis ini identik dengan Trinitas imanen. Intinya bukan untuk membuktikan Trinitas imanen dengan argumen rasional. Sebaliknya tentang kemungkinan menyimpulkan mulai dari pengalaman nyata ke kondisi di baliknya yang memungkinkan adanya pengalaman seperti itu. Di sini, dari kenyataan komunikasi diri Allah dalam dua cara, Rahner berpendapat bahwa kita dapat dan bahkan perlu untuk "menyimpulkan" dari Trinitas ekonomis keTrinitas imanen, karena kalau tidak

${ }^{22}$ Ibid., hlm. 99.

23 Karen Kilby, Karl Rahner (London: Harper Collins Religious, 1997) terjemahan Indonesia, komunikasi diri Allah tidak akan menjadi benar-benar komunikasi diri.

\section{Kesimpulan}

Karl Rahner selalu memperhatikan pribadi manusia yang secara eksistensial memiliki kerinduan bawaan kepada Tuhan. Menurut Rahner, hubungan dengan Allah merupakan sesuatu yang amat mendasar bagi keberadaan manusia. ${ }^{23}$ Studinya Di bawah Heidegger memungkinkan Rahner memperoleh antropologi teologis transendental. Hasilnya, dapat kita temukan dalam pemikiran Rahner tentang Trinitas sebagai suatu gerakan Allah menuju manusia serta keterbukaan manusia kepada Allah yang Trinitas. Inilah mengapa pemikiran Marechal amat penting bagi Rahner. Dia membantu Rahner menemukan cara untuk menyatukan pendidikan skolastik awalnya dengan filsafat kontemporer tentang pribadi manusia. Rahner menguraikan Thomisme transendental yang memberikan cakrawala bagi pribadi manusia untuk mengalami Allah yang Trinitas. Pengalaman seperti itu merupakan kesadaran diri manusia sebagai "ada dalam dunia" yaitu "ada" yang membutuhkan momen komunikatif diri Bapa melalui FirmanNya yang turun ke dunia dan karunia kasihnya melalui Roh-Nya. Umat kristiani sesungguhnya tidak hanya mendambakan suatu konseptualisasi atas kenyataan ini tetapi rindu pula untuk menerimanya dalam rutinitas sehari-hari agar mampu melihat Tuhan dalam segala hal. Inilah kontribusi

Hardono Hadi, Karl Rahner, (Yogyakarta: Kanisius, 2001), hlm. 16. 
Rahner untuk kita umat kristiani dewasa ini. Walaupun demikian kebanyakan orang Kristiani merasa tidak siap dalam menerima sumbangsih Rahner ini.

Melalui teologi Rahner kita dapat melihat hal-hal penting tentang pribadi manusia, dan apa yang Trinitas lakukan secara bebas namun misterius bagi kita. Dengan itu kita dibantu untuk lebih memahami tentang Yesus Kristus, karya penyelamatanNya, dan juga tentang Roh Kudus. Namun Trinitas tidak pernah mempengaruhi secara langsung anugerah kebebasan eksistensial yang kita miliki, sejarah yang kita jalani, kecenderungan kepada dosa dan pengalaman rasa bersalah yang kita alami. Semua ini merupakan hal-hal yang melekat pada kodrat manusia, tetapi Bapa dengan perantaraan Putera dan Roh-Nya tetap memberi kemungkinan dalam keaslian kodrati kita sebagai roh dalam dunia untuk menjadi pendengar firman.

Persepsi Rahner tentang tindakan Trinitas dalam kehidupan manusia sehari-hari meliputi beberapa hal di bawah ini: a) Pengandaiannya bahwa kita dapat mempelajari lebih dalam hubungan Firman yang kekal dan Yesus Kristus. b) Perhatiannya kepada kita untuk melihat Trinitas dalam segala hal. c) Gagasannya bahwa Trinitas adalah dogma sentral yang darinya semua doktrin lainnya mengalir. Ketiga hal ini perlu diinternalisasikan oleh umat kristiani dewasa ini. Pemikiran Rahner tentang Trinitas sesungguhnya dapat membantu beberapa pemahaman iman kristiani kita dan dapat terus bernilai, hanya jika dipelajari dengan cermat dan kemudian diterapkan secara nyata.

Di era pasca-modern ini, kelihatannya pemikiran klasik dari Agustinus atauThomas Aquinas kurang memadai lagi untuk memperkuat argumen kita tentang iman yang sejati kepada Trinitas. Hal yang sama tidak seharusnya berlaku pada pikiran Rahner yang hidup di abad kedua puluh. Rahner telah secara tepat menguraikan relevansi Trinitas bagi hidup manusia, sehingga kita tidak selamanya menganggap Trinitas sebagai doktrin yang terisolasi, dan menjadi amat jauh dari hidup nyata manusia.

\section{Daftar Pustaka}

Fatula, Mary Ann, The Triune God of Christian Faith, Minnesota: Liturgical Press, 1990.

Imhof, Paul dan Hubert Biallowons (eds.), Karl Rahner in Dialogue: Conversations and Interviews 19651982, (Terjemahan Inggris: Harvey D. Egan), New York: Crossroad, 1986.

Kilby, Karen, Karl Rahner, (London: Harper Collins Religious, 1997), terjemahan Indonesia, Hardono Hadi, Karl Rahner, Yogyakarta: Kanisius, 2001.

Krauss, Meinold, Karl Rahner: I Remember, New York: Crossroad, 1985.

Metz, J.B., A Passion for God, New York: Paulis, 1998.

Milton, Michael Kobus, The Doctrine of the Trinity According to Karl Rahner, dalam https://rdtwot.files.wordpress.com/2 007

Phan, Peter C., "Mystery of grace and salvation: Karl Rahner's theology of the Trinity" dalam Peter C. Phan (ed.), The Cabridge Companion to The Trinity, New York: Cambridge University Press, 2011. 
Rahner, Karl, Theological Investigations vol. XVI, New York: Crossroad, 1983.

, Spirit in the World, New York/ London: Herder and Herder / Sheed and Ward, 1968.

-, Foundations of Christian Faith: An Introduction to the Idea of Christianity, (trans. William V. Dych), New York: Seabury,1978.
--------, The Trinity, (terjemahan Joseph Donceel), New York: Crossroad, 1997.

Ted, Peters, God as Trinity: Relationality and Temporality in Divine Life, Louisville, Kentucky: John Knox Press, 1993. 
LUMEN VERITATIS: Jurnal Filsafat dan Teologi, Volume. 11 Nomor 1 Oktober 2020

pSSN 1978-3469; eISSN 2657-1927 